"Przegląd Prawa Konstytucyjnego" - Nr 2 (14)/2013 ------

\title{
Recenzja
}

\section{Rzeźbienie państwa prawa. 20 lat później. Ewa Łętowska $w$ rozmowie z Krzysztofem Sobczakiem, Wolters Kluwer Polska, Warszawa 2012, ss. 380}

Opracowanie Rzeźbienie Państwa Prawa. 20 lat później stanowi przekaz rozmów przeprowadzonych pomiędzy profesorem nauk prawnych Ewą Łętowską a dziennikarzem i publicystą prawnym Krzysztofem Sobczakiem. Pozycja ta opisuje przede wszystkim poglądy Ewy Łętowskiej, które ukształtowały w oparciu o jej doświadczenia nabyte podczas praktyki prawniczej w funkcji pierwszego rzecznika praw obywatelskich, sędziego Naczelnego Sądu Administracyjnego, sędziego Trybunału Konstytucyjnego oraz naukowca i dydaktyka. Należy zwrócić uwagę, iż prowadzący rozmowy redaktor Krzysztof Sobczak momentami również prezentuje swoje poglądy i opinie. Wskutek powyższego opracowanie dalekie jest od akademickiej formuły pytanie - odpowiedź. Przyjmuje ono raczej kształt dialogu dwóch równorzędnych podmiotów, w którym jedna strona prezentuje określony pogląd bądź stanowisko, często nie stroniąc od ocen (K. Sobczak), a druga poddaje je szerszej analizie oraz często poważnej krytyce. Pozycja nie ma charakteru ściśle naukowego, stąd też nie zawiera ona wielu odesłań do publikacji naukowych oraz polemik z poglądami przedstawionymi w doktrynie. Główny nurt rozważań skierowany jest przede wszystkim na praktykę stanowienia i stosowania prawa, stąd też w opracowaniu tym autorzy umieścili wiele odwołań do orzeczeń sądów, w szczególności administracyjnych i Sądu Najwyższego, oraz trybunałów, w tym Trybunału Konstytucyjnego oraz Europejskiego Trybunału Praw Człowieka.

Tytuł opracowania nawiązuje do dwóch kwestii. Po pierwsze odnosi się on do procesu powstawania demokratycznego państwa prawa, któ- 
ry w ocenie Ewy Łętowskiej nie zakończył się na uchwaleniu Konstytucji Rzeczypospolitej Polskiej z dnia 2 kwietnia 1997 r. pani profesor uważa, że w tej dziedzinie Państwo Polskie wiele już osiągnęło, ale i bardzo wiele ma jeszcze do zrobienia, w szczególności jeżeli porównamy obecny kształt ustroju RP do efektów uzyskanych przez „stare” i silnie ugruntowanie demokracje zachodnie oraz do standardów ukształtowanych przez Europejski Trybunał Praw Człowieka. Tytuł książki, opierający się na słowie „rzeźbienie”, ma odzwierciedlać stosunkowo żmudny i pracochłonny proces tworzenia nowoczesnego państwa, który wymaga planu, przemyślanej koncepcji i współpracy wielu osób i instytucji. W ocenie pierwszego rzecznika praw obywatelskich Rzeczpospolita jest stosunkowo młodą demokracją i ma jeszcze wiele do zrobienia w zakresie przebudowy państwa w kierunku nowoczesnego ustroju demokratycznego. W powyższej materii nie są konieczne jakieś radykalne i gruntowne zmiany prawa i systemu prawnego, potrzebna jest natomiast zmiana podejścia osób interpretujących i stosujących prawo. Profesor poddaje poważnej krytyce stricte pozytywistyczne podejście do wykładni prawa, które oparte jest na dyrektywach językowych i literalnym (ścisłym) interpretowaniu przepisów prawnych i pojęć w nich zawartych, w szczególności w oderwaniu od ich aksjologicznego kontekstu i celu (skutku), jaki mają osiągnąć.

Druga cześć tytułu, 20 lat później, ma podwójne znaczenie. W pierwszej kolejności odnosi się do upływu 20 lat od uzyskania przez Polskę pełnej suwerenności i możliwości niezależnego konstruowania swojego ustroju. Niebagatelne doświadczenie zawodowe Ewy Łętowskiej, które kształtowało się w czasach dochodzenia do demokracji i okresie dwóch dekad zdefiniowanego konstytucyjne demokratycznego państwa prawa, dają autorce silne podstawy do analiz i wniosków. W tym ujęciu tytuł odnosi się do książki Aleksandra Dumasa (ojca) $W$ dwadzieścia później i oznacza, jak sama autorka wskazuje, że „upływ czasu nie oznacza braku nadziei” (s. 376). Mimo upływu dwóch dekad i pewnego skostnienia struktur państwa i niechęci do przemian środowiska prawnicze i polityczne nadal posiadają pokłady siły dzięki którym można coś zmienić w rzeczywistości społecznej i prawnej. W tej płaszczyźnie rozważań autorka przypisuje ogromne znaczenie do nowoczesnych standardów demokratycznego państwa prawa, do których Państwo Polskie winno dążyć. Autorka wskazuje, iż standardy te ulegają zmia- 
nom i obecnie różnią się od tych które obowiązywały 20 lat temu, i że nie można zaprzestać działań zmierzających do ulepszania państwa, poszerzania ochrony jednostki. Rzeczpospolita po uchwaleniu ustawy zasadniczej uwzględniającej wymagania ustroju demokratycznego nie może spocząć na laurach i ma obowiązek dalszego rozwoju, pogłębiania demokracji i idei $\mathrm{z}$ nią związanych. W ocenie autorki same prawo to nie wszystko i nie wystarczą przepisy ustawy zasadniczej, które stanowią, że „Rzeczpospolita Polska jest demokratycznym państwem prawnym"1, potrzebna jest bowiem ciągła praca elit nad udoskonalaniem systemu.

W drugim ujęciu tytuł recenzowanej książki nawiązuje do piosenki Jacka Kaczmarskiego, również zainspirowanej książką Aleksandra Dumasa Dwadzieścia lat później, z albumu Dwadzieścia (5) lat później (2000 r.). Ta inspiracja ma już charakter znacznie mniej optymistyczny i dużo bardziej krytyczny w stosunku do osób piastujących stanowiska w ramach trójpodziału władzy oraz w stosunku do środowisk prawniczych, naukowych i politycznych. Piosenka J. Kaczmarskiego opowiada o postarzałych muszkieterach, którzy są zgorzkniali, cyniczni, wzbogaceni ekonomicznie, lecz wyzbyci głębszych ideałów. Taką krytyczną ocenę profesor Łętowska przypisuje środowiskom polityków, którzy w imię własnych korzyści i realizacji krótkoterminowych założeń stanowią na chybcika i doraźnie prawo, które jest bardzo dalekie od doskonałości i wywołuje więcej szkód niż korzyści dla adresatów. Głównym zarzutem stawianym politykom jest instrumentalne podejście do prawa. Podejście to de facto nie zmieniło się od czasów PRL (s. 350). $\mathrm{W}$ ocenie profesor Łętowskiej politycy podczas stanowienia prawa nie biorą pod rozwagę opinii i stanowisk przedstawianych przez przedstawicieli nauki i praktyków. Autorka konkluduje, że politycy „psują prawo i państwo”. Były rzecznik praw obywatelskich zwraca uwagę na fakt kreowania przez te środowiska bardzo szkodliwego zjawiska, które nazywa „zarządzanie strachem”. Polega ono na wytwarzaniu w społeczeństwie niepewności, braku zaufania i stanu ciągłego zagrożenia. Rządzeni mają ustawicznie czuć, że coś jest z nimi nie tak i że władza może to w każdej chwili wykorzystać przeciw-

1 Por. art. 1 Konstytucji Rzeczypospolitej Polski z dnia 22 lipca 1952 r. (Dz.U. 1976, $\mathrm{Nr} 7$, poz. 36 t.j. ze zm.) w brzmieniu ustalonym ustawą o zmianie Konstytucji Polskiej Rzeczypospolitej Ludowej z dnia 29 grudnia 1989 r. (Dz.U. Nr 75, poz. 444) oraz art. 2 Konstytucji Rzeczypospolitej Polski z dnia 2 kwietnia 1997 r. (Dz.U. Nr 78, poz. 483 ze zm.). 
ko nim. Ten socjotechniczny środek z powodzeniem wykorzystywany być w systemach totalitarnych. Niestety wykorzystywany jest również do manipulowania społeczeństwem (bądź grupami społecznymi) również w rzeczywistości demokratycznego państwa prawego. W ocenie autorki takie zjawisko przykładowo miało miejsce w sytuacji tzw. ustawy lustracyjnej (s. 168) i sprawy porozumieniem ACTA (s. 370).

Ewa Łętowska również krytycznie, choć trochę mniej surowo, ocenia prawników, zarówno przedstawicieli nauki, jak i praktyków. Zarzuca im interesowność, brak bezstronności, obiektywizmu i zbyt częstą uległość wobec polityków. Pani profesor poddaje krytyce również środowisko sędziowskie, które, w jej ocenie zbyt sztywno i formalnie podchodzi do wykładni językowej, pomijając reguły wykładni celowościowej i systemowej. Autorka wskazuje, iż „przepis to mało, potrzebna dobra praktyka”, której niestety często brakuje. Pani profesor zauważa, że środowiska sędziowskie podchodzą z bardzo dużym sceptycyzmem, często również i niewiedzą, do standardów wypracowanych przez europejskie trybunały. Rzutuje to na ochronę jednostki, która odbiega od poziomu zachodnioeuropejskiego. Ponadto dużym problemem jest pomijanie w orzecznictwie (w szczególności sądów niższych instancji) przepisów polskiej ustawy zasadniczej i dorobku orzeczniczego Trybunału Konstytucyjnego.

Książka składa się z 16 rozdziałów, wstępu napisanego przez Krzysztofa Sobczaka oraz posłowa napisanego przez Ewę Łętowską. Każdy rozdział poświęcony został jednemu zagadnieniu, które w ocenie uczestników rozmowy zasługuje na szczególną uwagę ze względu na jego znaczenie społeczne, prawne, polityczne lub aksjologiczne. Wszystkie poruszone przez autorów zagadnienia związane są z obowiązywaniem, stanowieniem, derogacją i stosowaniem prawa. Rozmówcy w poszczególnych rozdziałach kładą nacisk na różne aspekty omawianych zagadnień. W niektórych częściach pracy rozważania pani profesor koncentrują się przede wszystkim na płaszczyźnie jurydycznej omawianych problemów, np. praworządność (s. 11, r. I); Kościelna Komisja Majątkowa (s. 48, r. III), tymczasowe aresztowanie (s. 105, r. V), prawo do sądu (s. 141, r. VI), dyskryminacja (s. 250, r. XI), zasada niedziałania prawa wstecz i zaufanie do państwa (s. 268), spór Sądu Najwyższego z Trybunałem Konstytucyjnym (s. 335, r. XIV). W innych profesor przedstawia swoje przemyślenia, koncentrując się przede wszystkim na kontekście etycz- 
nym bądź aksjologicznym omawianych zagadnień, np. religia w szkołach (s. 20, r. II), aborcja (s. 78, r. IV), lustracja (s. 168, r. VII), stosunek polityków do prawa (s. 350, r. XV). Niezależnie od zasadniczego charakteru poruszanego problemu i nacisku na jego etyczny (aksjologiczny) bądź jurydyczny charakter wszystkie zagadnienia zostały zanalizowane w oparciu o różne konteksty w szczególności prawny etyczny aksjologiczny i politycznym.

Profesor Ewa Łętowska zwraca uwagę na pozytywne aspekty poruszanych zagadnień, jednakże kryterium doboru tematów poszczególnych rozdziałów były dysfunkcjonalne zjawiska (skutki) związane z ich istnieniem. Przede wszystkim wokół tych negatywnych elementów i potrzeby ich zmiany koncentrują się rozważania autorki. Przedstawia ona jakiś problem natury prawniczej lub aksjologicznej związanej z prawem i konieczność jego usunięcia. Autorka nie zawsze przedstawia uniwersalny sposób jego rozwiązania, albowiem czasami taki po prostu nie istnieje, lub snucie teoretycznych analiz nad jego ewentualną skutecznością jest bezprzedmiotowe. Autorka wówczas wskazuje na obowiązek organów władzy publicznej i innych podmiotów podjęcia działań (czasami nawet metodą prób i błędów) zmierzających do jego usunięcia. Najbardziej krytycznie ocenione są zaniechania organów władzy, polityków i prawników w tych materiach. Często jest tak, że w ogóle nie próbują oni zmierzyć się z problematycznym zagadnieniem i traktują je tak jakby ono nie istniało lub starają się je usunąć za pomocą półśrodków, środków zastępczych lub całkowicie nieskutecznych. W ten sposób wytwarzają w społeczeństwie przekonanie, że problem został rozwiązany, gdy tymczasem w rzeczywistości żadne skuteczne środki zaradcze nie zostały przedsięwzięte.

Układ rozdziałów w całości pracy nie ma charakteru chronologicznego, nadto tematy nie zostały uszeregowane od najbardziej doniosłego do najmniej istotnego. Kompozycja opracowania stanowi raczej zestawienie niezwiązanych ze sobą lub luźno połączonych tematów. Podstawowym i raczej formalnym łącznikiem wszystkich rozdziałów jest fakt, iż każde poruszone w książce zagadnienie wiąże się z istnieniem jakiegoś poważnego problemu, który wywołuje negatywne konsekwencje i potrzebę podjęcia czynności naprawczych, usprawniających funkcjonowanie państwa albo wzmacniających ochronę jednostki. Nadto poruszane zagadnienia niosą ze sobą duży ładunek aksjologiczny wywołujący spory w orzecznictwie sądów, wśród polity- 
ków, prawników oraz przede wszystkim w społeczeństwie. Niektóre przemyślenia autorki mające istotne znaczenie dla poruszonego problemu zostały wyróżnione poprzez ujęcie ich w ramce. Nadaje to szacie graficznej książki trochę podręcznikowy charakter. Równocześnie zwraca to uwagę czytelnika na szczególnie doniosłe fragmenty opracowania, które posiadające kluczowe znaczenie dla omawianego problemu.

Hasłem-kluczem, które można odnaleźć w całości pracy i które stanowi jedno z powiązań poszczególnych jej części, jest słowo „standard”. Dla autorki oznacza on pewien wzorzec postępowania o dużym znaczeniu, z reguły wynikający z przepisów prawa, który ponadto realizowany jest w praktyce organów stosujących prawo (s. 12). Standardy wynikają z Konstytucji RP, wiążących Polskę umów międzynarodowych, orzecznictwa Trybunału Konstytucyjnego i Europejskiego Trybunału Praw Człowieka. W całej pracy autorka nawołuje do polityków, prawników, praktyków, sędziów, naukowców itp. do podejmowania czynności zmierzających do osiągania i realizacji standardów nowoczesnego i demokratycznego państwa prawa. Równocześnie wielokrotnie autorka sygnalizuje, że mimo niebagatelnych osiągnięć Rzeczpospolitej w zakresie urzeczywistniania i wdrażania reżimu demokratycznego wiele standardów jest naruszanych zarówno przez prawodawcę ustanawiającego przepisy prawne, jak i przez organy stosujące prawo w tym w szczególności sądy.

Książka Rzeźbienie państwa prawa. 20 lat później nie stanowi podsumowania naukowej i zawodowej pracy profesor Łętowskiej. Jest ona raczej próbą zmierzenia się autorki $\mathrm{z}$ wybranymi problemami o charakterze jurydycznym i aksjologicznym oraz próbą podjęcia polemiki z zaistniałymi w środowiskach prawniczych poglądami i krytyki społecznie szkodliwych zjawisk. Opracowanie to nie ma charakteru ściśle prawniczego i cechuje się dużą interdyscyplinarnością. Porusza ono zagadnienia z zakresu prawa, polityki, socjologii, politologii, etyki. Nie ma ono również charakteru naukowego. Stanowi ono wynik przemyśleń autorki nad problemami trapiącymi polską rzeczywistość prawną, polityczną i społeczną. Kanwę całości rozważań i ocen profesor Łętowskiej stanowią jej doświadczenia jako zawodowego prawnika oraz naukowca. Autorka podjęła się bardzo trudnego zadania analizy, oceny i krytyki dysfunkcjonalnych zjawisk, często niejednoznacznie postrzeganych $\mathrm{w}$ doktrynie i praktyce. Jej rozważania osadzone są w regula- 
cjach prawnych, praktyce orzeczniczej sądów i trybunałów oraz kontekście społecznym. Książka ta stanowi ważny punkt wyjścia dla dalszego badania i oceny poruszonych w niej tematów oraz podejmowania próby usuwania i naprawy szkodliwych skutków omówionych w niej problemów. „Rzeźbienie państwa prawa. 20 lat później” jest pozycją bardzo wartościową, godną uwagi i polecenia.

Marcin Dąbrowski (Uniwersytet Warmińsko-Mazurski w Olsztynie) 